\title{
Spanish, Portuguese, and Neo-Latin Poetry Written and/or Published by Seventeenth- and Eighteenth-Century Sephardim from Hamburg and Frankfurt (1)
}

Kenneth BROWN University of Calgary

\section{INTRODUCTION}

In the latter part of the sixteenth century, small communities of Sephardic Jews from Portugal, Italy, Flanders, and Spain began to settle in the commercial northwest Germany port cities of Hamburg, Altona, Glückstadt, Emden, and Lübeck ${ }^{2}$. They

\footnotetext{
1 The author herein wishes to express his sincere appreciation to the following individuals and institutions for helping to promote this study: the Deutscher Akademischer Austausch Dienst (DAAD), for providing him a "Travel/Research Grant» to Hamburg and Wolfenbüttel (Germany), during the summer of 1994 and the autumn of 1998; Dr. Eva Horváth, Curator of the Handschriftenabteilung (Manuscript Section), Staats- und Universitätsbibliothek Hamburg (SuUH, from here onward), who provided him ready access to materials during his study there and who guided him to other important Sephardica collections in that city; Dr. Michaël Studemund-Halévy, personal friend and Hamburg savant, who introduced him, firsthand, to the cultural wealth of the seventeenth- and eighteenth-century Hamburg Sephardic community; Dr. Monika Richarz, Director of the Institut für die Geschichte der Deutschen Juden (Hamburg), for making accessible the Institut's valuable and extensive library collection. And, last but not least, thanks go out to my colleagues Dr. Héloise Séailles, and Dr. María de los Reyes Bertolín, who offered great aid in the translation of the Latin verses.

2 Population figures are: in 1603, 7 families and 2 apprentices; in 1612, 125 persons; in 1703, 13 families. Vid. The Universal Jewish Encyclopedia [TUJE] 1941, Vol. V p. 192, s.v. «Hamburg»; The Jewish Encyclopedia [TJE] 1907, Vol.
} 
were prominent Sephardim: former crypto-Jews to whatever degree and/or former professing Christians of Jewish descent or not who openly embraced Judaism ${ }^{3}$.

These Iberian Jews were involved in shipbuilding and whaling, finance and importation of raw goods from the Spanish and Portuguese colonies, and goldsmithing. Others distinguished themselves as a fervent anti-Jewish orthodox polemicist -Uriel da Costa (in Hamburg ca. 1616) ${ }^{4}-$; a physician, philosopher, and mathematician -Manoel Bocarro Francês (= Jacob Rosales; 1588-1662) ${ }^{5}-$; a grammarian -Mosseh Gidhon Abudiente (1602-1688)-, a lexicographer and physician -Benjamin Mussaphia (1609-1672)-; and an imperial notary -Abraham Meldola (1754-1829) 6-. There were occasional poets among them: the subject of the present study.

In the same time period, Ashkenazi Jews from German-speaking lands settled in close proximity to their Sephardic coreligionists, but the relationship, predicated on the myth of «Sephardic supremacy», would never be fluid ${ }^{7}$.

The Sephardim living on the Elbe possessed their own Bet Ya'akov ha-Katan synagogue/community, an ample cemetery founded in 1611 in nearby Danish Altona, on the Königstraße, and editorial presses.

From 1618 to 1785 (which, incidentally, is the time period of interest to this study), at least twenty-five books in Portuguese and Spanish were printed in Hamburg and environs by the local Sephardic community ${ }^{8}$. The manuscript count is nonexistent, but must be equally small in number. Biblical texts in Hebrew had begun to appear as early as 1586 , the handiwork of Christian editors and printers ${ }^{9}$.

\footnotetext{
VI p. 191, s.v. «Hamburg»; and The Encyclopaedia Judaica [TEJ] 1971, Vol. VII cols. 1225-1229; and KELLENBENZ 1989 p. 29.

${ }^{3}$ There has been a running debate concerning the definition of degrees of crypto-Judaism and the classification of the marranos or Jewish converts to Christianity. See RÉvaH 1959-1960, KaPLAN 1994, and LIPINER 1985. MÉCHOULAN 1991 p. 12 considers marrano a misnomer, preferting crypto Jew.

${ }^{4}$ Méchoulan 1991 pp. 41-46.

5 Consult RÉVAH 1957 and the second part of this study, when it appears.

- TUJE pp. 192-193.

7 See SCHORSCH 1989; MÉCHOULAN 1991 pp. 58-65; KAPLAN 1996.

${ }^{8}$ STUDEMUND-HALÉVY 1997a, 1997d, and 1997e pp. 153-157.

9 TEJ 1971, Vol. VII col. 1225: section on «Typography».
} 
The remains of the Sephardi cultural and religious heritage in Hamburg and vicinity are today mere shadows of what was once a thriving, albeit small, socioeconomic and cultural presence. Remnants can still be found on partially effaced and fractured tombstone inscriptions in the Altona cemetery. What the elements did not erase, World War II Allied bombings did. Cultural artifacts, such as ornately decorated seventeenthcentury Jewish marriage contracts (ketuboth) prepared for Sephardic couples, are proudly on display in Hamburg's Museum für Hamburgische Geschichte; and there are the exceedingly rare printed editions and a handful of manuscript sources of the literatures of the Hamburg-based Sephardim.

Their linguae francae were primarily Portuguese and Spanish, but neo-Latin, Hebrew, German, Dutch, English, as well as French would also find their way into the printed and manuscript media ${ }^{10}$.

Many of the Hamburg-based Sephardim would abandon the city, eventually emigrating to Copenhagen, Amsterdam, Venice, or Leghorn. In 1697, an excessive poll tax on Jews prompted the wealthiest to move to Danish Altona and Dutch Amsterdam; also, internal squabbles among the Jewish population divided the congregants, causing further dispersion. The "withdrawal [in the mid seventeenth century] of Jacob Abensur (minister resident of the king of Poland) and his followers" is yet another major reason given for the subsequent decline of Hamburg's Sephardic community ${ }^{11}$.

In 1619 and in Leghorn or Pisa, Italy, the recent convert to Judaism Shlomo Abudiente (once Portuguese Christian and Franciscan monk in Madrid) would scribble the following dedication in his poetic songbook: "Ao muito magnífico Señor iahacob abudiente que el dio guarde em Liorne ... amstardam ... hamburgo» ${ }^{12}$. Such an itinerary exemplifies the «Sephardic

\footnotetext{
${ }^{10}$ An apt example is Cod. Hisp. 44, Universitätsbibliothek Hamburg, Collecção curioza de poesias \& en prosa, em português, castelhano, francês, anglêz [sic], collegido por Bento Guilhelmo Rahmeyer, late seventeenth-early eighteenth century, which contains texts, some dealing with Jewish subject matter, in all these languages. A second example of a multilingual literary text is Jeosúah Habilho's Nueva Colección in Brown 1997.

11 TUJE 1941 p. 193; and TJE 1907 p. 192.

12 BROWN 1998a.
} 
connection» in northern Europe. A second example is Paulo de Pina, Lisbon-born converso, who left for Rome in 1599 with the intention of becoming a monk. Instead, there he converted to Judaism, adopting the name Rehuel Jessurun. The author of the Jewish auto sacramental the Diâlogo dos montes (ed. 1975), he lived in Amsterdam yet died in Hamburg in 1635.

The transitory Spanish and Portuguese literary legacy of these displaced Sephardim in northern Germany is incomplete, frustratingly sketchy. So much so that Johann Rist, in his Musa Teutonica (1640) and Neuer Teutscher Parnass (1652) completely ignores the existence of a different body of poetry in Hamburg and other German-speaking cities. But so does Leonard Forster ${ }^{13}$. Johann Christoph Wolf, the great Germanic scholar and hebraist, in his Bibliotheca Hebraea (1715-1733) was aware of particular instances of creative writing among individual Hamburg-based Sephardim, such as Jacob Rosales and Moses Gidhon Abudiente, but only for bibliographical sake ${ }^{14}$.

In fairness to modern German literary historians, blame for this oversight or ignorance should be assumed by their contemporary Iberian homologues. The Spanish José Amador de los Ríos in the mid-nineteenth century (1848) ${ }^{15}$, the Hungarian Meyer Kayserling in the same period (1859 and 1890), the Spanish Marcelino Menéndez Pelayo at the onset of the twentieth century (1910) ${ }^{16}$, and the French Camille Pitollet (1910) ${ }^{17}$ were aware of this literary phenomenon, but understood its crucial importance at a distance and with a superficial critical bent. That was generations ago.

My topic deals with the subject of «Seventeenth- and eighteenth-century Sephardic exile literature in Hamburg and Frankfurt», of «Iberian provincial literature written and/or pub-

${ }^{13}$ In his essay «Deutsche und Europäische Barockliteratur» (1977) pp. 31-53, as well as in his Studien zur europäischen Rezeption deutscher Barockliteratur (1983) pp. 7-11. Neither BECKER-CANTARINo, nor HOFFMEISTER 1977, nor TIEMANN 1936 mention it.

${ }_{14}$ Bibliotheca Hebraea (Hamburg and Leipzig 1715) Vol. I: Rosales, no. 1108, p. 615 , where he mentions the poet's "Poculum Poeticum" and "Carmen intellectuale», poems which will be included in part 2 of this study; Gidhon ABUDIENTE, no. 1534 , p. 816.

15 Chaps. V-XI pp. 535-655.

16 1946, 1963 pp. 285-323: «Los judaizantes».

17 Pp. $165-176 ; 1911$ pp. 360-367, pp. 466-472. 
lished in Hamburg and Frankfurt by the diasporic Sephardim», and of «Spanish colonial and/or Creole literature authored and/or published by Sephardim in German-speaking cities». What emerges from this historiographical nomenclature and its tautological variants is a literary, linguistic, and sociological phenomenon, the product of a micro or minority society in a seventeenth- and eighteenth-century German-speaking world.

Few poetic texts still remain to tell us a story, however partial it might be, of a keen obeisance to Judaism, of a devotion to the official languages of political oppression (that is, the Spanish and Portuguese of the Inquisition and the Expulsion), of the lives of the poets. Much presumably has been lost.

For instance, manuscript Hispan. 32, summarily described in the F. Eyssenhardt Catalogue ${ }^{18}$ with its poems in Spanish and Portuguese (ff. 38-39) -a possible indication of its Sephardi authorship-, and an interlude (entremés) El tudesco (ff. 40r-44r) -possibly referring to 'The Ashkenazic Jew'- ${ }^{19}$ perished, probably in the feuerstorm, the Allied bombings of Hamburg in 1943. Jacob Rosales' (Manoel Bocarro Francês) Brindis Nupcial (Hamburg 1632), which must have been a narration or extended epithalamium plus verse eclogue celebrating Isaak and Sara Abás' marriage, has yet to be located ${ }^{20}$.

Hamburg's Municipal Archive possesses some of the Portuguese (= Sephardic) Community's protocol books. Judaica/ Hebraica/Sephardica literary texts are found in the Universitätsbibliothek Carl von Ossietzky, whose H. B. Levy Collection of Hebrew Manuscripts and printed books is now less-

\footnotetext{
181897 p. 18.

19 According to MÉchoulan 1991 pp. 58-65, esp. p. 61, section devoted to "Les Ashkenazes", the term tudesca would be used to refer to domestic employee of Ashkenazi background'. The term, in its masc. or fem. forms, connotes a Jewish German (or Yiddish)-speaking individual of inferior social rank.

${ }^{20}$ Not located in Germany, the U.S., Madrid or Lisbon. Listed in KAYSERLING 1890 p. 96: «Brindis Nupcial é égloga panegyrica, representada dos Senhores Isach e Sara Abas. Hamburg 1632. 8. 'Cette allégorie est précédée d'une sorte de dialogue allégorique de Yeosua Abendana'». Kayserling may have merely copied this information from the Catalogue de la collection ... de livres et manuscrits hébraiques, espagnoles et portugais ... de la bibliothèque de Mr. Isaac da Costa, red. par M. RoEsT (Amsterdam 1861).
} 
than-complete ${ }^{21}$. Supposedly, seventy-five percent of the University Library's manuscript collection was destroyed or disappeared after the 1943 Allied bombings. It has been suggested that Russian troops carted away many library treasures ${ }^{22}$.

According to bibliographical sources ${ }^{23}$, before World War II in Hamburg there was also a Museum für Jüdische Volkskunde, that no longer exists, but which has been superseded by the Institut für die Geschichte der deutschen Juden; the Institute possesses secondary literature, several rare Sephardic published texts, and many of the Cassuto Family papers. (The Cassutos were a distinguished family of local historians ${ }^{24}$.) In 1842, the new Portuguese synagogue on the Altewall-Strasse, «together with the valuable archives», was completely consumed in the great Hamburg fire ${ }^{25}$.

The salvaged texts are still partially legible on Hamburgarea tombstones, in prefatory poems to unique and/or quite rare published volumes, in a single chapbook published at Hamburg in 1764, and in a collection of Psalms of David published at Frankfurt in 1626, as well as in manuscript miscellanies from London, Brussels, Amsterdam, Jerusalem, and Philadelphia.

The lost voices of the Sephardi Parnassus in Hamburg, and, possibly, Frankfurt, during the seventeenth and eighteenth centuries are those of Ishak Abás, David Abenatar Melo, Daniel Abudiente, Manoel Bocarro Francês (= Jacob Rosales), Eliachim Castiel, Joseph Francês, Mosseh Gidhon Abudiente, Jeosúah Habilho, Ishak de Herrera, Abraham Meldola, Emanuel Nahmías de Castro, Paulo de Pina (= Rehuel Jessurun),

21 See Verzeichniss 1900; ROTH - STREIDL 1984.

22 In personal conversation with Dr. Eva Horváth. Since Mozart musical scores have recently been returned by the Russians to the Hamburg University Library («Not Even Mostly Mozart, But Clearly Some», The New York Times [June 12, 1997] pp. A1 and A19), it remains to be seen whether missing Hebraica and Judaica texts will reappear.

23 TUJE p. 196.

24 See, for instance, Studemund-Halévy 1999a, and «Alfonso Cassuto und der Portugiesenfriedhof an der Königstraße», in his 1997c pp. 721-752.

$25 T U J E$ p. 193. 
and, tangentially, Benjamín Senior Godines and Ishak de Matatías Aboab's father: the count comes to at least fourteen men, though no women writers ${ }^{26}$. Five additional poems are anonymous.

In the first section of the present study, I intend to provide representative examples from each author's works, assessing the poetic discourse for reasons of linguistic exclusion ${ }^{27}$, autobiography, broad cultural aspects, and the connection with the Iberian Golden-Age muse.

In the Appendix to the study is a modernized edition of almost all the poems in Spanish, Portuguese, and Neo-Latin I have located written by the Germany-based seventeenth- and eighteenth-century Sephardim. Excluded is Jeosúah Habilho's poetry ${ }^{28}$, and the one-hundred-fifty psalms of David translated by David Abenatar Melo (1626) ${ }^{29}$. Included, however, are that author's prefatory poems, other verses that couch this last edition, and a poem by D. A. M. included in an Amsterdam manuscript miscellany.

Part two of this study will include newly discovered poetic texts by Jacob Rosales, Abraham Meldola, and Emanuel Nahmías de Castro, some significant correspondence, additional poetic funereal inscriptions, and an argument bolstering the Frankfurt connection.

\section{THE COLECCIÓN NUEVA}

The most complete corpus poetarum we possess of any Sephardi poet writing from or about Hamburg is Jeosúah Habilho's Colección Nueva de canciones lyricas, unas colegidas de los más célebres ingenios y otras compuestas por Jeosúah Habilho (Hamburg 1764) ${ }^{30}$. A hundred-page chapbook in both Spanish and Portuguese, the Colección Nueva represents an unknown or forgotten and very late link in the rich Iberian

\footnotetext{
${ }^{26}$ This is surprising since in both Amsterdam and London Sephardi women wrote poetry. See BROWN 1998b.

27 RIANDIÈre LA ROCHE 1983.

28 In BROWN 1997.

29 See BOER 1997, and STUdEMUND-HALÉVy 1999 b and 1999 c (forthcoming).

30 BROWN 1997.
} 
tradition of divine and profane poetry collections, known under the rubric of «Poesías Sacras y Profanas».

If in the oft-cited Die Memoiren der Glückel von Hameln (5451 [= 1690-1691]), published by Kauffman in the original Judeo-German in Vienna 1896, and subsequently translated to English by Lowenthal (1932), the author, «geboren in Hamburg 1645, gestorben in Metz 19 September 1724» ("born in Hamburg in 1645, died in Metz, 19 September 1724'), could tell her now-famous story of the Hamburg Ashkenazi community of her generation ${ }^{31}$, Jeosúah Habilho could recount his story of the Sephardim in Hamburg in his Colección Nueva: a novel and ingenious text.

At first glance, Habilho's is a volume for pleasure reading by an archtypical Iberian seventeenth-or eighteenth-century literary consumer: «Si con ánimo sencillo / me recibes sin regüeldo, / yo te fío que otro sueldo / presto pagues a Habilho». The chapbook then evolves into a type of Jewish gebetbuch ('prayerbook') replete with verse vindications of Mosaic Law and «extra»-patriotic Judaism, presented in predominantly anacreontic (that is to say, 'neoclassical') strophic forms. The following poem, though, is a romance (ballad):

De una montaña desciende el Propheta más perfecto,
a ser espejo de todo, de mirarlo quedan ciegos.
Muy presuroso desciende para enseñarles al pueblo
la Ley santa que escribió de Dios mismo el sacro dedo.
Lo primero que les dice, es: -iQue adoréis por extremo
al grande Dios de Israël, que Él es sólo el verdadero!-.

The Spanish-Christian reader conveniently excluded from these piyyutim, the Colección Nueva then becomes a wistful pan-European liederbuch of amatory poems accompanied by eighteen tunes from the early eighteenth-century European voice repertoire. For instance, Jeosúah Habilho asks his Jewish reader to sing the Spanish neo-Garcilasian anacreontics $-\ll \mathrm{O} O \mathrm{O}$, dulce prenda, / templa mi ciego ardor / ya que fulminas / rayos de amor!»- to the tune of the popular «Igh mag nicht lieben» ('I'd Rather Not Love'), and the equally amatory «Después que vi, / que vi con mis antojos / a tus hermosos ojos / al punto

31 See also Lowenthal 1936, Chap. 12: «Grand Dukes in Jewry». 
me rendí» to the Dutch or Flemish tune of «Ma Matie lief» ('My Mathilde's [?] Going').

As the poetic text adopts the Portuguese language, the discourse is transformed into a linguistic means for recounting the carnivalesque-like festivities of Purim as it was celebrated most likely in Amsterdam, the Jewish holiday corresponding to the bearing of first fruits of Spring in the agricultural cycle and to the story of Esther and her people in the quasi-liturgical one (poem XXXII):
Quanto dinheiro leva a festa de Purim em sonhos e fatias que custão boms florims. Pastelinhos de anjo e bom vinho do Rim, assados e melinas com outras couzas mil ... Com fausto desmarcado convidão um sem fim que comen seu dinheiro e zombão do festim. Porém dos que mais gastão da gente do candil são só os estudantes que vão a os Medrassim.

In the same editorial space, the Colección Nueva also becomes an excuse for autobiographical ranting about the petty internecine squabbles among the members of the Hamburg Sephardic community. A prime example are the «Versos que fêz Jeosúah Habilho a seu irmão porque não lhe quis falar estando muito doente, e a sua mulher haver mandado una humilde carta, e não querer responder (Em dia de Purim, d'este ano 5506 [= 1727], em Amsterdam. A voz de "Yigdal Elloüm Hay"» (poem 44):

Ouví de um certo homem que entisicou; seu irmão morto do fomem nunca falou. Todo é a altiveza que lhe causou tirarse de pobreza, certo a passou, certo a passou.

Com todo é perverso, não arrependeu dos males, que comverso, logo esqueseu, quando de Hamburgo viu e o recolheu um bruto muito feio the pareceu, the pareceu.

Jeosúah Habilho is the gemeine spielleute ('the popular singer of songs') par excellence, who has intelligently fused the neopastoral love ethos and fluid lyricism of the Spanish Golden 
Age with the musical repertoire of eighteenth-century panEuropean popular song and Jewish canonical liturgy. Eric Werner ${ }^{32}$ calls «the musical tradition of the Jews from central Europe the minhag [מנהג 'custom'] ashkenaz». Consequently, Jeosúah Habilho's creation could be deemed the minhag sephardi.

\section{OTHER VERSE}

Anecdotal to our thesis is Ishak de Matatías Aboab's «Versos que fêz meu señor pai a minha señora mai índose para Hamburgo a buscar a minha tia Rivca Justa, e era casado de poucos anos» ${ }^{33}$. What is unique about this poem, dating approximately from 1640 and supposedly authored by Ishak de Matatías Aboab's father, a Sephardic Jew who departs from his wife, en route from Amsterdam to Hamburg, is a human expressive quality which we in literary studies used to call «authenticity» or «authentic human emotivity». Obvious in this décima is its epistolary intent (see strophe 1).

Equally anecdotal are romance-language epitaphs inscribed on tombstones in Altona's Jewish Friedhof. Dated 1681, that of a reputable poet reads: «Do Bemaventurado / \& Virtuoso Varão / Joseph Francêz sua / alma goze da Glória / Faleceo $5^{\text {a }}$ Feira $1^{\circ}$ de R: ['Thursday, the first of'] Nissan / Anno 5441»; from 1688, we read: «Sepultura do Insigne / E Eminente Senhor H. H. [Hehaham Hagaon 'The eminent sage'] / Ribi Mosse Abudiente / Que el Dio Recolheu para / sí em 2 de Veadar $\mathrm{A}^{\circ}$ 5448 / Sua alma gose da glória»; and from 1801, a bi-lingual Hebrew/Portuguese tombstone for Benjamin Musaphia Fidalgo: «Aquí jaz o Anciano \& muy Benaventurado Binjamin Musaphia Fidalgo Author dos Versos Poêticos / que se achão ao outro lado desta Louza, os quais compós em sua vida, / para lhe servir en vez de Epytáphio. Passou desta para a outra / milhor, em 24 Tebeth do $A^{\circ} 5561$, da Idade de 89 As ['years'] 3Ms ['months'] 15Ds ['days'] / Deixando por successão 2 Filhos, / 1 Netto, 3 Nettas \& 5 Bisnettos / Sua Alma Gose da Glória». Unfortunately, the «Versos Poêticos» have been effaced.

\footnotetext{
321976 p. 1.

33 Appendix, no. 19.
} 
One of several verse epitaphs still legible is that for the hazan Jacob Rephael Cohen Belinfante (1761), whose Hebrew text includes 8 verses in Portuguese. The first strophe's concision and wordplay based on opposites - bem/ mal, mal/bem- and on ascending degrees -merecer/lograr, padecer/penar-resembles that common to texts in the Iberian fifteenth-and early sixteenthcentury cancionero tradition:

Tão bem esto[u] com meu mal despois que perdí meu bem que o bem me parece mal e o mal me parece bem.
A dita de merecer não a poder bem lograr sem primeiro padecer a cabo de bem penar ${ }^{34}$.

We may add to this funerary poetry the perfunctory rhymed admonishments in Spanish by Benjamín Senior Godines, who was in Amsterdam in 1682. Max Grunwald ${ }^{35}$ reproduced the following inscriptions of his containing momento mori: "Cuenta estrecha, pena eterna / y ves rigoroso, ¡Ay del perezoso!»; «Oh tú, que me estás mirando, / mira bien que vivas bien, / que no saber hora ni cuándo / te verás así también»; "Haz aquello que quisiera / haber hecho cuando muera»; and «Una [sic] ánima tienes y no más, / si la pierdes, ¿qué harás?».

\section{PREFATORY POEMS}

The final examples of Iberian-language poetry penned in Hamburg are prefatory poems and psalms published in printed texts. The following three are by Joseph Francês, about whom Miguel/Daniel (Leví) de Barrios would write: «Joseph Francés, armado de conceptos, / guardó del Pindo harmónicos precep-

34 SARRAGA 1997 pp. 36, 40, 43-45, 49; see also STUDEMUND-HALÉVY 1997b, and Weinstein 1997. Consult Brombacher 1989 and HenríuUz de Castro 1883. In FAUST - STUDEMUND-HALÉVY 1997 p. 70, the original reads "a pude», which is phonologically possible but grammatically incorrect.

351902 p. 27. These examples of momento mori are on display at London's Jewish Museum. 
tos». Central thematics are normal death and extraordinary martyrdom with subsequent glorification. The Spanish Jew Miguel/Daniel (Leví) de Barrios (b. 1631 Montilla, Córdoba, d. 1701 Amsterdam) prepared the introduction to our first example:

Illustró al Pueblo Hebreo Hamburgués con su exemplar observancia Mosayca, y con sus poéticas expresiones, entre las qüales viene este Epitafio al Jaxam Ischac Jesurum de Hamburgo:

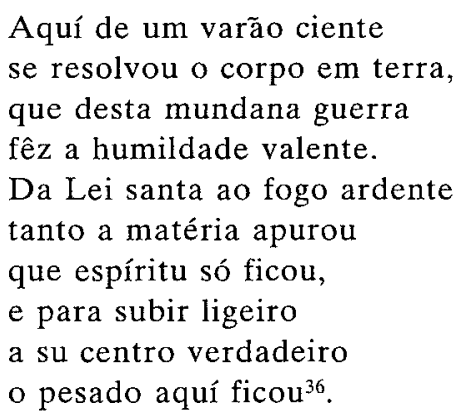

A second poem appears in Mosseh Gidhon Abudiente's Gramática Hebraica (Hamburg 1633). Here the occasional poet compares Mosseh Gidhon to the patriarch of the Israelites who led his people from bondage; the contemporary Moses can lead his brethren from the darkness of ignorance with the light of erudition provided by his Hebrew grammar book (see Appendix, 4.1-2). No matter how ingenuous this discourse might seem to us, we must not forget how crucial Nebrija's Spanish grammar book, the Gramática de la Lengua Castellana (1492), was for establishing the language of the Spanish empire.

In his funerary Elogios que zelosos dedicaron a la felice memoria de Abraham Núñez Bernal, que fue quemado vivo santificando el nombre de su criador en Córdova a 3 de mayo 5415 (Amsterdam 1655), Francês' ingenious conceit, «ardiente amor» (see Appendix 15.4a), is employed to refer to the martyr's sacrifice for his religious beliefs.

${ }^{36}$ Barrios writes varón instead of varão (v. 1), resolvó (v. 2), and y (v. 8). KAYSERLING 1890 p. 286; also in YERUSHALMI 1971 p. 199 (Appendix, no. 16). This tombstone plus inscription is reproduced photographically in FAUST STUDEMUND-HALÉVY 1997 p. 60. 
M. Menéndez Pelayo's evaluation of the Sephardic literature written in exile in the north of Europe (1910) is still the most often repeated and quoted: "La literatura de los judaizantes españoles del siglo XVII, lo mismo que su ciencia, no tiene originalidad ni carácter propio; antes sigue todas las vicisitudes de gusto propias de la general española» ${ }^{37}$.

His introduction to David Abenatar Melo's lacklustre translation of the Psalms (Frankfurt 1626) ${ }^{38}$ shall be the starting point for the penultimate section in this study, on other prefatory poems and the Psalms themselves: «Poeta bíblico fue David Abenatar Melo, fugitivo de las cárceles de la Inquisición en 1611, y autor de una mediana traducción de los Psalmos, inferior, no sólo a las muestras que nos dejaron Fr. Luis de León y Malón de Chaide, sino a la del Maestro Valdivielso, y hasta a la del conde de Rebolledo, a pesar de su falta de color poético».

The sole constructive and adulatory remark of his is that in some passages -especially those in Moses' first canticle- Abenatar Melo infuses his prosaic discourse with «fuerza y color poético». We have become too accustomed to Menéndez Pelayo bashing of late to understand the perspicacity of his criticism. He was mostly right. Let us, however, review the prefatory poems by others and some of David Abenatar Melo's Psalms to appreciate their significant passages. Read, for instance, in Appendix, Poems: 1.6a; 2.5b-c7; 3.2; 4.2f-j; 5.4; $6.3-$ $4 ; 7.3 ; 9.1 ; 10.3 ; 12.19-28,37-38,45-46,63-64 ; 14.5 \mathrm{c}-\mathrm{d}$; and $28.12 \mathrm{a}-\mathrm{b}$. This reading will then lead to my conclusions.

\section{CONCLUSIONS}

To conclude the historical section of this study, one should bear in mind the several distinct and disparate sources of poetry, the topics they communicate, and their place of com-

37 Obras completas, pp. 285-323, corresponding to Book V, Chap. II: «Los judaizantes». This Vol. IV, «Protestantismo y sectas místicas», is XXXVIII in the entire series.

${ }_{38}$ Text likely published by a Frankfurt-based Calvinist press tolerant and supportive of religious heterodoxy and intellectualism. This matter will be addressed in the second part of this study. See Evans 1975. See also GrozINGER Jüdische Kultur 1997. 
position. The numerical count is at least forty published and manuscript poems (approximately twelve to appear in my second part), one printed chapbook, one translation of the Psalms, several verse epigraphs, and four funerary admonishments. There are no prose novels, no drama (except for Rehuel Jessurun's awkward mystery play), no literary letters, and no critical essays.

Many of these works were written in Amsterdam or for Amsterdam-based literary and/or religious activities. I pose the following question: Is the Sephardi Parnassus in Hamburg and Frankfurt merely an aside in the Sephardic literature of exile from Spain and Portugal, an anecdote in the history of Iberian provincial letters, a footnote to Spanish colonial literatures? The answer undoubtedly is in the affirmative, but my conclusions address a more significant sociocultural reality: that is, the Hamburg- and Frankfurt-based Sephardim, as did their Amsterdam and Italian coreligionaries on a much more ambitious and impressive scale, attempted to recreate but also create a distinct nature of Spanish and Portuguese Golden-Age poetry in the north of Europe.

This poetry had its own newly-created mythology, replete with a cadre of fresh martyrs and heroes - a second Moses, a revived flesh-and-blood David, a new Isaac, a Jewish «Apollo»-. These figures were not merely set-pieces or rigid topoi, but conscious choices of a reborn leadership to guide the forgotten sons of the Israelites to a renewed preeminence. This literature boasted a new Hebrew grammar that contained comparative sections from Spanish and Portuguese verse writing ${ }^{39}$; it counted new translations from the «classics» (in this case, the Psalms).

This Sephardic poetry told the story of a new way of life, one never entirely divorced from a former one in inquisitorial Iberia. Its story was new and mature enough to recount the coffeehouse adventures of the picaresque Jeosúah Habilho, whose poetic chapbook was so aptly titled Colección Nueva, because its piyyutim in Spanish, its Bildungsroman / Schelmenroman (picaresque narration) in Portuguese, and its mise en musique in any one of several European and classical languages was, in

${ }^{39}$ Maleakhi 1994; KlijnSmit 1994. 
fact, incredibly novel for 1764. Hardly anyone gets terribly excited about Spanish neoclassical literature; the Colección Nueva with its touch of Rococo spice is a pleasant exception. Alles geschah als Spanisch, Portugiesich und Neulatein in Hamburg und Frankfurt gesprochen und gedruckt wurden.

Or this poetry could tell of a bourgeois couple whose parting became the stuff of real verse on the prosaic matter of matrimonial fidelity. It could also recount the humiliation of the inquisitorial dungeon, the loss of children and family. This was a conscious creative process undertaken on a micro scale.

When one studies the intense Spanish- and Portuguese-language literary productivity of the seventeenth- and eighteenthcentury Sephardim in Amsterdam, Leghorn, and Venice -literatures with Hebrew translations of the Greco-Roman classics, such as Aesop's fables ${ }^{40}$ and Ovid's Metamorphoses ${ }^{41}$, as well as Isabel Rebeca Correa's Spanish translation of a major work of the Italian Renaissance, Guarini's 16th-century Il Pastor Fido ${ }^{42}$, and the anonymous aljamiado translation of Ariosto's Orlando Furioso ${ }^{43}$, the Hebrew translation of the late medieval/early Spanish renaissance classics Celestina ${ }^{44}$ and Amadís de Gaula ${ }^{45}$, even the Hebrew-language translation of Racine's drama Esther ${ }^{46}$, and of fresh Spanish-language burlesque epics recounted in ingenious gongorine and quevedesque conceits

${ }^{40}$ MSS. Kaufmann A.547 BASHB, and ADD 26.916 The British Library. In the Katalog (1906) of the Kaufmann Colleccion, Library of the Hungarian Academy of Sciences (Budapest) p. 174, the following information is given: «... f. Ital. v. Hebr. Favoli d'Esopo. Aesopus' Fabelu B. II, 43-83 ins Hebr. übers u. Raffael Fontanella Colorne. $22 \mathrm{ff} »$.

${ }^{41}$ The British Library, MSS. Kaufmann A.547 BASHB and ADD 26.916. The following description is offered in the same 1906 Katalog: «Metamorphoses. $4^{\circ}$. Pap. Ital. mit hebr. Cop. aus dem Original Mscr. 1825 v. Gabriel Trieste u. Söhne. Das original Mscr. Schenken Sie der Mantuaner Synagogenbibliothek. S. Mortara, f. 37, Thes. 580/599. Marini [מאריני] Sabbatai Chajim's שירי החליפות hebr. Übersetzung der Metamorphos. Ovids mit Ital. Texte. I, II, VIII. Gesang Index der griechischen Namen wie sie hebr. Zurückgegeben sind».

42. López Estrada 1994a, 1994b.

${ }^{43}$ Minervini 1997. A comparable phenomenon may exist in Ashkenazi literature. FUKS - FUKS-MANSFELD 1987, Vol. II p. 457, no. 632, summarily register a Yiddish verse rendering of the Sir Gawain story (Amsterdam 1683).

44 CASSUTO 1935.

45 Maleakhi 1982.

${ }^{46}$ KNAPP 1974. 
and discourse ${ }^{47}$-a larger picture emerges of an attempt to create a literature that could rival and reinvent some of the most resounding literature Europe had to offer at the time.

\section{BIBLIOGRAPHY}

Abenatar Melo, David. 1626. Los CL Psalmos de David: en Lengua Española, en varias rimas conpuestos por David Abenatar melo, conforme a la verdadera Traducción ferraresqua: con algunas aleguorías Del Autor. Dedicados al D.B.Y. y a su santa conpanha de Yssrael y Jeudad: esparzida por el mundo en este larguo cautiverio, y al cabo la Baraká Del mismo David y Cántico de Moyzés. En Franquaforte Anho de 5386 [=1626] em 24 de elul.

$\mathrm{ABOAB}$, Ishak de Matatías. 1683. Relações, cantigas, adevinhações $e$ outras corizidades: The British Library, MS. Add. 18155, $40 \mathrm{ff}$.; and La Bibliothèque Royale de Bruxelles, MS. II 93, 41 ff.

ABUdiente, Mosseh Gideon. 1633. Gramática Hebraica: Parte primeira. Onde se mostram as regras nesessárias assim para a inteligéncia da língua, como para compor e escrever nella em proza e verso, com a elegáncia e medida que convem. Por Moseh filho de Gidhon Abudiente. Em Hamburguo: 3 de Elul. Anno de criasam 5393.

AEsop. Fables [Hebrew translation]: Library of the Academy of Sciences (Budapest), MS. Kaufmann A.548, Oriental Collection.

AMADOR DE LOS Ríos, José. 1848. Estudios históricos, políticos, y literarios sobre los judíos de España, Chaps. V-XI pp. 535-655. Madrid.

BarretT, R. D., and W. M. SChwab. 1989. The Sephardi Heritage, vol. II. Grendon, Northants: Gibraltar Books.

BARrios, Daniel Leví de. See KAYSERLing 1890.

BeCKer-CANTARINo, Barbara, 1983. «Spain in German Literature of the Seventeenth Century», in HOFFMEISTER 1983 pp. 109-123.

Boer, Harm den, and Monserrat Gómez GARcía. 1997. «Los salmos de David (Abenatar Melo)», in STUDEMUND-HALÉvy (Ed.) 1997c pp. 753-780.

Brombacher, J. A. 1989. «Poetry on Gravestones: Poetry by the 17th-Century Portuguese Rabbi Solomon de Oliveyra Found in the Jewish Cemetery at Ouderkerk aan de Amstel», in MiCHMAN pp. 153-166.

Brown, Kenneth. 1994. «La poesía de Abraham Gómez Silveira (ca. 1645-ca. 1720) y David del Valle Saldaña (1699-1755): la musa

47 BROWN 1994 and 1999a. 
sefardita en el exilio de Amsterdam canta voces del Siglo de Oro español», in Los judaizantes en Europa y la literatura castellana del Siglo de Oro (Madrid) pp. 77-95.

- 1997. "The Spanish and Portuguese Golden Age Parnassus in Hamburg: Jeosúah Habilho's Colección Nueva (1764), in Die Sefarden in Hamburg (Hamburg) Vol. II pp. 781-878.

-_- and Mariano GÓMEZ ARANDA. 1998a. «A New Collection of Seventeenth-Century Spanish and Portuguese Poetry from Italy and its Sephardic Connection», Romance Philology 52 pp. 45-70.

-- 1998 b, with Stephanie KARAU. «La poetisa es la luna que con las de Apolo viene: nuevos datos y textos de varias poetisas sefardíes de los siglos XVII y XVIII", in La Creatividad Femenina y las Trampas del Poder (Kassel) in press.

---, and Harm den BoER. 1999. Abraham Gómez Silveira ...: el Quevedo sefardí. Estudio preliminar ... Kassel: Reichenberger, in press.

Buarque de Holanda Ferreira, Aurélio. 1975. Novo Dicionário da Língua Portuguesa. Rio de Janeiro.

Cassuto, Umberto. 1935. «The First Hebrew Comedy» [Hebrew text], in Jewish Studies in Memory of George A. Kohut, Eds. Salo W. BARON and Alexander MARX (New York) pp. 121-128.

1648 [?]. Elogios varios que curiosos diversos dedicaron al martirio de Ishak de Crasto Tartás, que en Lisboa fue quemado vivo, por santificaçión del nombre del Señor Dios á 23 de Deciembre de 1647. The Historical Society of Pennsylvania / The Library Company of Philadelphia, MS. Log. 195 Q, ff. 94r-99r.

1664 or 1665 [?]. Elogios Que zelosos dedicaron a la felice memoria de Abraham Núñez Bernal, que fue quemado vivo santificando el nombre de su criador [sic] en Córdoba a 3 de mayo 5415. Amsterdam.

Evans, R. J. W. 1975. The Wechel Presses: Humanism and Calvinism in Central Europe 1572-1627, in Past and Present, Supplem. 2.

EysSEnHARDT, F. 1897. Die spanischen Handschriften der Stadtbibliothek. Hamburg: Grafe \& Sillem.

FAUST, Jürgen, and Michaël Studemund-HalÉvy. 1997. Betahaim: Sefardische Gräber in Schleswig-Holstein. Glückstadt: J. J. Augustin.

FORSTER, Leonard. 1977. Kleine Schriften zur deutschen Literatur im 17. Jahrundert. Amsterdam: Rodopi.

_- Ed. 1983. Studien zur europäischen Rezeption deutscher Barockliteratur. Wiesbaden: Harrassowitz.

Fuks, L., and R. G. Fuks-MANSFELD. 1984, 1987. Hebrew Typography 
in the Northern Netherlands 1585-1815: Historical Evaluation and Descriptive Bibliography. 2 parts. Leiden: Brill.

GlüCKel von HAMELN. 1910. Die Memoiren der Glïckel von Hameln geboren in Hamburg 1645, gestorben in Metz 19. September 1724, Ed. Prof. Dr. David Kaufmann. Vienna.

---. 1936, 1970. The Memoirs of Glïckel of Hameln, Trans. Marvin LOWENTHAL. New York.

Grimal, Pierre. 1984. Diccionario de mitología griega y romana. Barcelona.

GröZINGER, Karl E. Ed. 1997. Jüdische Kultur in Frankfurt am Main: von dem Anfängen bis zur gegenwart, Band 1. Wiesbaden: Harrassowitz.

Grunwald, Max. 1902. Portugiesengräber auf deutscher Erde. Hamburg.

Henríquez dE CASTRO, D. 1883. Keur van Grafsteenen op de Nederlandsche Portugese Israëlitische Begraafplaats te Ouderkerk aan de Amstel. Leiden.

HofFMEISTER, Gerhart. 1976. Spanien und Deutschland: Geschichte und dokumentation der literarischen Beziehungen. Berlin: Erich Schmidt.

- 1983. German Baroque Literature: The European Perspective. New York: Ungar.

Jessurun, Rehuel. 1975. Diâlogo dos montes, Ed. Philip Polack. London.

--. 1907. The Jewish Encyclopedia, Vol. VI. New York - London.

KAPLAN, Yosef. 1989. "The Portuguese Community in 17th-Century Amsterdam and the Ashkenazi World», in MICHMAN pp. 23-45 (Repr. in KAPLAN 1996 pp. 78-106).

---. 1994. "Wayward New Christians and Stubborn New Jews: The Shaping of a Jewish Identity», Jewish History 8/1-2 pp. 27-41.

---. 1996. Judios nuevos en Amsterdam: Estudio sobre la historia social e intelectual del judaísmo sefardí en el siglo XVII. Barcelona.

KAySERling, Meyer. [1859], 1972. Sephardim: Romanische Poesien der Juden in Spanien (Ein Beitrag zur Literatur und Geschichte der Spanisch-Portugiesischen Juden). Leipzig: Hermann Mendelssohn; Reed. Hildesheim - New York.

---. 1889, 1971. «Une Histoire de Ia Littérature Juive de Daniel Lévi de Barrios», Revue des Études Juives 18 pp. 276-289; Repr. by Yosef Hayim Yerushalmi (Ed.), in M. Kayserling Biblioteca Española-Portugueza-Judaica and other studies in Ibero-Jewish bibliography, by the Author, and by J. S. da SILVA ROSA; with a 
bibliography of Kayserling's publications by M. WEISZ (New York) pp. 189-202.

-. 1890, 1971. Biblioteca Española-Portugueza-Judaica. Strasbourg; Reimpr. New York, with a Prolegomon by Y. H. YeRUSHALMI.

KELlenbenZ, Hermann. 1989. «History of the Sephardim in Germany». In BARRETT - SCHWAB 1989.

KLIJNSMIT, Anthony J. 1994. «'Se qual o ouro entre todos os metais' Abudiente's Hebrew Grammar (1633)», in STUDEMUND-HALÉVY KOJ pp. 319-374.

KNAPP, Bettina L. 1974. «Jean Racine's Esther and Two Hebrew Translations of this Drama", in Salo Wittmayer Baron Jubilee Volume (Jerusalem) Vol. II. pp. 591-621.

LIPINER, Elias. 1985. "O cristão-novo: mito ou realidade?», in Ed. Yosef KAPLAN, Jews and Conversos: Studies in Society and the Inquisition (Jerusalem) pp. 124-138.

-_. 1992. Izaque de Castro: O mancebo que veio preso do Brasil. Recife.

López Estrada, Francisco. 1994a. «Isabel Rebeca Correa: Defensa de la mujer escritora en el Amsterdam sefardí del siglo XVII", in Los judaizantes en Europa y la literatura castellana del Siglo de Oro (Madrid) pp. 261-272.

- - 1994b. «Poética barroca. Edición y estudio de los preliminares de El Pastor Fido de Guarini, traducido por Isabel Correa (1694)», in Hommage à Robert Jammes, Anejos de Criticón 1 (Toulouse) pp. 739-753.

Lowenthal, Marvin. 1936. The Jews of Germany: A Story of Sixteen Centuries. Philadelphia.

Machado, José Pedro. 1977. Dicionário Etimológico da Língua Portuguesa. 3rd ed. Lisboa.

MaleAkHI, Zvi. 1982. The Loving Knight: The Romance of Amadis de Gaula and Its Hebrew Adaptation. Petah-Tikva, Israel; orig. Turkey ca. 1541.

--- 1994. "L'Oeuvre littéraire de Moses Gideon Abudiente», in STUDEMUND-HALÉVY - KOJ pp. 307-318.

MÉChoulan, Henry. 1991. Être juif à Amsterdam au temps de Spinoza. Paris.

Menéndez y Pelayo, Marcelino. 1963, 1946. Historia de los heterodoxos españoles, Vol. IV: «Protestantismo y sectas místicas» (= Vol. XXXVIII of the M. M. P.'s Obras completas), Ed. D. Enrique SÁNCHEZ REYES (2nd ed. Madrid) pp. 285-323 (= to Book V, Chap. II: «Los judaizantes»).

Mrchman, Joseph. Ed. 1989. Dutch-Jewish History, Vol. II. The Netherlands \& Jerusalem (Ongoing series). 
Minervini, Laura. 1997. «An Aljamiado Version of 'Orlando Furioso': A Judeo-Spanish Transcription of Jerónimo de Urrea's Translation», in Hispano-Jewish Civilization After 1492 (Jerusalem) pp. 191-202.

Morais Silva, António de. 1922. Grand Dicionário da Língua Portuguesa. 10th ed. Rio de Janeiro.

OviD. Metamorphoses [Hebrew translation]: Library of the Academy of Sciences (Budapest), MS. Kaufmann A.547.

---. Metamorphoses [Hebrew translation]: The British Library, Oriental Collection, MS. ADD 26.916.

PITOllet, Camille. 1910-1911. «Sur un recueil hambourgeois de poésies judéo-hispaniques», Revista de Archivos, Bibliotecas y Museos 23 pp. $165-176 ; 24$ pp. 360-367, pp. 466-472.

RÉVAH, Israel, S. 1957. «Une famille de 'nouveaux-chrétiens': les Bocarro Francês», Revue des Études Juives n.s. 16/116 (jan.-déc.) pp. 73-87.

_-_. 1959-1960. «Les Marranes», Revue des Études Juives 118 pp. 2977.

RIANDiÈre la Roche, Josette. 1983. «Du Discours d'Exclusion des Juifs: Antijudaïsme ou Antisémitisme?», in Les Problèmes de L'Exclusion en Espagne (XVIe-XVIIe siècles): Idéologie et discours (Paris) pp. 139-155.

RIST, Johann. 1640. Musa Teutonica. Hamburg: Gundermann.

---. 1652. Neuer Teutscher Parnass. Lüneberg: Steinen.

ROTH, Ernst, and Hans STREIDL. 1984. Hebräische handschriften in Deutschland, 3: Die Handschriften der Sammlung H. B. Levy an der Staats- und Universitätsbibliothek Hamburg. Wiesbaden.

SARRAGA, Marian and Ramón. 1997. «Some Episodes of Sephardic History as Reflected in Epitaphs of the Jewish Cemetery in Altona», in STUdEMUND-HALÉVY 1997c pp. 661-719.

SCHORSCH, Ismar. 1989. «The Myth of Sephardic Supremacy», Year Book of the Leo Baeck Institute 34 pp. 47-66.

Studemund-HaLÉVy, Michaël. 1994. Bibliographie zur Geschichie der Juden in Hamburg. München - New Providence - London - Paris.

---. 1996. «Panorama de L'Épigraphie Funéraire Judéo-Portugaise à Hambourg», in Mémoires Juives D'Espagne et du Portugal (Paris) pp. $105-125$.

--. 1997a. «Sephardischer Buchdruck in Hamburg: erster Teil», Lusorama 32 (March) pp. 85-101.

-- . 1997b. «Les Sépharades Oubliés D’Allemagne», La Lettre Sépharade 23 pp. 10-11.

--. Ed. 1997c. Die Sefarden in Hamburg: Zur Geschichte einer Minderheit, Vol. II. Hamburg. 
-_. 1997d. "Hamburger Autoren und ihre Bücher», Lusorama 33 (Juni) pp. 41-72.

- - . 1997e. "Sephardische Bücher und Bibliotheken in Hamburg», Menora 8 pp. $150-180$.

--. 1997f. «Die portugiesisch-spanischen Grabinschriften in Norddeutschland: Glückstadt und Emden», Aschkenaz 7 pp. 389-439.

--. 1999a. «O Livro dos Minhagim de Hamburgo: uma Estranha Odisseia», in Dulce et decorum est philologiam colere: Festschrift für Dietrich Briesenmeister ... (Berlin) pp. 1143-1167.

- - 1999b. «Zwischen Amsterdam und Hamburg: Sephardische Bücherschicksale im 17. Jahrhundert», Sonderdruck aus Romania Judaica 3 pp. 69-92.

-- . 1999c. «Roteiro de uma vida: Fernão Alvares Melo alias David Abenatar Melo», Ibn Marvan (forthcoming).

Studemund-Halévy, Michael, and Peter KoJ. 1994. Die Sefarden in Hamburg, Vol. I. Hamburg.

Sylva de diferentes discursos y argumentos sobre varios subgetos: The Jewish National and University Library (Jerusalem), MS. EH HS 48 A 23 [early eighteenth c.].

1941. The Universal Jewish Encyclopedia, Vol. V. New York.

TIEMANN, Hermann. [1936], 1971. Das spanische Schriftum in Deutschland von der Renaissance bis zur Romantik. Hildesheim [Hamburg]: Olms.

1900. Verzeichniss [= Index] der Judaica aus der Sammlung des Herrn H[aim] B[aruch] Levy in Hamburg. Hamburg.

Weinstein, Rochelle. 1997. "The Storied Stones of Altona: Biblical Imagery on Sephardic Tombstones at the Jewish Cemetery of Altona-Königstraße, Hamburg», in STUDEMUND-HALÉVy 1997c pp. 551-660.

WeIsz, Max. 1906. Katalog der Hebräischen Handschriften und Bücher in der Bibliotek des Professors Dr. David Kaufmann. Budapest. In Magyar: Néhaí Dr. Kaufmann Dávid Tanár Könyvtárának Héber Kéziratai És Könyvei Összeállitja És Ismerteti Dr. Weisz Miksa.

Werner, Eric. 1976. A Voice Still Heard: The Sacred Songs of the Ashkenazic Jews. Pennsylvania.

Yerushalmi, Yosef Hayim. See Kayserling 1889, 1971. 


\section{APPENDIX}

For the present edition of poems, I have modernized the orthography and punctuation of the manuscript and printed originals. The following norms have been followed: 1) defective readings in Portuguese and Spanish -whether they be printer's errors or authorial misspellings- are corrected to reflect modern usage; 2) scribal abbreviations are resolved within italics; 3 ) the use of $b, v$, and $u ; i, j$, and $y ; h$, and $i ; u$, and $\ddot{u}$; and $s, s s, z, c ̧$, and $c$ is regularized and modernized, as are other orthographical peculiarities; 4) Portuguese renderings of Spanish words (e.g., lhamé, instead of the Sp. llamé) as well as Spanish renderings in Portuguese (e.g., mozo, instead of the Port. menino) are maintained.

\section{Doctoris Jacob Rosales ad Librum Ode ${ }^{48}$ :}

Ito per docti meditantis ora,

Liber, aeterna tripodans corona;

Liber, a morsu inuidiae profanant

Haud sacra sacri.

5] Haud valet linguae dominus dolosae In sacram linguam furere; \& canino Inuidus partem nequit inde sanctam Dente ferire:

Si doces linguam, eloquium que caeli,

10] Quis loqui laudes poterit docentis?

Haud locum mendax rabide latrare, lingua tenebit:

I, pedi laeto, bona causa (uicta Hoste doctorum inscitia) triunfat:

15] Non opus quaerit rigidi patroni Candida uirtus:

Quid? si, ouans Liber, sibi, uocem coeli Nunc vocas; discant homines loqui cum Jam Deo; gaudet propria poli rex

20] Voce uocari.

Hac sacrae nobis Deitatis adflat

Numen: hac nobis loquitur salutis Hac viam ostendens animas ab atro Amouet orco;

25] Igneas que Alti penetrare suadens Januas, tecum reserat cataenas, Angeli agnoscent propria colonum,

${ }^{48}$ Gramática Hebraica (Hamburg 1633) fol. [3r]. 
Voce loquentem.

Ergo sub lucem rutilando, Liber,

30] Jam veni lucem nitidumque lumen

Afferes nobis; Superumque terram.

Lingua docebit.

Cum tuo vives Gedeone nato,

Mose, in aeternum, placidaeque Mosi

35] Gratiae adflabunt, ubi cum beatis

Vivere viso ${ }^{49}$.

\section{Ejusdem Doctoris [Jacob Rosales]; Epygramma ${ }^{50}$}

Hic docet in Lingua proprioque idiomate Moses

Linguam caelestis, dictaque sancta Chori:

Hanc disce \& disces superum commercia, linguam

5] Tunc aliam in sacris ignis amoris habe:

Hac Deus ad nos, adque illum nos pellimur istis:

Haec homines reddet mutua lingua Deo ${ }^{51}$.

49 'Book, pass to the mouth of meditative sage; / Book, [like the Phythonissa], seated on the eternal Delphic Tripod; / Book, [despite] the murmur of envy sacred things are not profaned. I The wise man pays no attention to the deceitful tongue / that suggests rage against the sacred word; and the envious one can not therefore / gnarl at that which is sacred. / If you teach the language and eloquence of heaven, / who will [then] be able to praise the teachings of the master? [= Who can do better?]/The lying tongue will have no place to bark with rage: / You, Book, go forward happily, / good cause will triumph once ignorance has been eradicated by the wise minions. / Candid virtue does not question the work of a steadfast tradition [= Judaism]. / What? [Why?] You, Book that praises, if you now call to yourself the voice of heaven, I may men learn now how to speak with God. / The King of Heaven will rejoice when addressed in his own voice. / The inspiration of the holy deity, / for that reason, resonates on our behalf. / That is why it speaks to us about salvation. / That is why by showing us the path, / it diverts souls from the black inferno and, / convincing us to transcend the burning portals of heaven, / it opens the chains for you. / The angels recognize the colonist [= poet] who speaks with his own voice; / that is why Book as you shine in the light, / I have already come to brightness, / and you bring the brilliant light to us. / The language [= Hebrew] will teach the earth the divine. / Having been born your Gideon, / you will live eternally as Moses. / And the calm graces of Moses / will blow when I contemplate life / among the contented [in heaven]'.

so Gramática Hebraica (Hamburg 1633) fol. [3v]

51 'Here Moses will teach with and in his own tongue / the language of heaven and the sacred words of the choruses. / Learn this and you will learn the intercourse of the gods. / Then speak another language in the sacred fires of love: / By this and by these things, God to us and we to Him will be driven: / Let this reciprocal [= borrowed] language bring men back to the gods'. 
3. Ao autor [Mosseh Gidhon Abudiente], De Daniel Abudiente seu tio; Soneto ${ }^{52}$

1] Penetrar os sofísticos enganos que ofuscão a pureza da verdade qualquer pode alcançar, a que a idade descobre em largo tempo os desenganos.

2] Mas fonte fabricar por cujos canos se augmente no falar propiedade na língua, novo ser e utilidade, só vós podeis fazer ternos anos.

3] Crescei, Robi Mosseh, que se ao respeito em vós saber e idade vão crescendo, assombro de ums sereis, e de outros guia.

4] Nem é alheo em vós tão alto efeito pois sol que quente vêm logo e nacendo prognostica abrasar ao meio dia.

4. De Joseph Francês; Décimas ${ }^{53}$

1] Entre as chamas corroscantes nos celestes horizontes, trêmulos os firmes montes, humildemente arrogantes nos foi dada a lei, mas antes que a comunicar Mossé porque com arte nós dé luz de seus pontos altivos nos soberanos archivos, profundos mistérios vê.

2] Foi recebendo Israel cabalística a doctrina já quasi a nos clandestina no cautiveiro cruel; mas neste horror de Babel en vez de em Sinay, permite Deus que esta arte facilite quanto o galut dificulta e o que de Mosseh sepulta, outro Mosseh rescucite.

${ }^{52}$ Gramática Hebraica (Hamburg 1633) fol. [5r].

${ }^{53}$ Gramática Hebraica (Hamburg 1633) fol. [5v]. 
5. De Ishak Abás ao autor [Mosseh Gidhon Abudiente]; Soneto ${ }^{54}$

1] Na lusitana língua, que a memória da santa facilite a retentiva arte, que do princípio o fim deriva do recto ensino vós promete a glória.

2] A ciência sem arte é falsa história, caduca na memória preceptiva, que como o rudimento a não cultiva fica sem fundamento, é transitória.

3] Vós em método puro, claro e docto gramaticando do princípio ao meio, o fim mostrais, se estás sempre ignoto.

4] Hoje que a luz, o Mosé sábio!, vejo de vossa musa a luz vencendo a Loto 55 . título adquirireis de Apolo Hebreo.

6. Soneto de un amigo [Anon.] al autor [David Abenatar Melo] 56

1] ¡O músico real na hebrea lira! Cantou do sumo Deus altos louvores, as grandezas, milagros e os favores do povo que ao bem somente aspira.

2] Também profetizou a horrenda ira a dura sanha os ásperos rigores a os impios e perversos transgressores da santa lei que as manchas da alma, tira.

3] Outro David na cítara castelhana os sagrados mistérios comunica as remotas nações con zêlo santo.

4] E imitando aquela harpa soberana os segredos do céu aquí publica en concertada rima e doce canto.

\footnotetext{
${ }^{54}$ Gramática Hebraica (Hamburg 1633) fol. [7r].

55 Loto 'the fruit of the lotus tree', here a personification for the loss of memory; GRIMAL 1984 p. 328.

${ }^{56}$ Los CL Psalmos de David (Frankfurt 1626) fol. [6v].
} 
7. De outro amigo [Anon.], al autor [David Abenatar Melo]; Soneto ${ }^{57}$

1] Mucho alienta al cansado su reposo $y$ al marinero el puerto deseado, la apelación concedida al condenado, salir del campo el flaco victorioso.

2] Al buen pintor su painel curioso, su rebanho al pastor en fértil prado, al buen músico su rabel templado y al mercader que trata ser dichoso.

3] A todo esto tu pluma ha excedido nel método de tu verso y arquitectura, con que al psalmista ensalzas y sublimas.

4] Manifestando al mundo por tus rimas la gloria y el valor de tu pintura con armonía y dado $[s i c]$ esclarecido.

8. De outro amigo [Anon.] ao autor [David Abenatar Melo]; [Soneto] ${ }^{58}$

1] As virtudes e ciência que mostrares componendo obra tão santa e sem igual farão por sempre ilustre e imortal a felice memória que cobrastes.

2] E aqueles a quem tanto aproveitastes dando doutrina mais que natural a qui terão perpétuo e bom final dos secretos da lei que penetrastes.

3] Pois se o real David profetizando deixou mistérios grandes encubertos, a nosso vário e incerto pensamento,

4] Vós manifestamente interpretando, con tão sábios conceitos e tão certos, nos aclarais o fraco entendimento.

57 Los CL Psalmos de David (Frankfurt 1626) fol. [6v].

58 Los CL Psalmos de David (Frankfurt 1626) fol. [7r]. 
9. Soneto de Ishak de Herrera ao autor [David Abenatar Me10] ${ }^{59}$.

1] Quem viu em verso heróico tan conceito?

Em espanhola língoa tal verdade?

Em zêlo mais que humano a piadade?

A virtude perfeita em tal sugeito?

2] Quem viu tirar do íntimo do peito mais zêlo do que hai na humanidade? Quem pôs en un romance gravidade se não este David que o es perfeito?

3] Se o nome em perfeição, Senhor, mostrastes, no zêlo da fé pura desprezando, quantos bens o terreno pôde dar?

4] Em esta obra que o é a luz tirastes, neste mundo vós fica já ilustrando, e no eterno fará laurear.

10. De outro amigo de casa [Anon.], ao autor [David Abenatar Melo]; [Soneto] ${ }^{60}$

1] Davão do nome as obras bom indício quando sendo tão mozo comenzastes a encaminhar os vozes que tornastes fazendo de pastor o mesmo ofício.

2] Não vós faltou tão bem o céu propício, pois tanto en terra estranha prosperastes mostrando n'ela o zelo que mostrastes em desprezar do mundo o avaro vício.

3] David guiou ovelhas, vós as vozes, David venceu gigante, vós un mundo, que em vós vencer a vós tanto fizestes.

4] Êsse vós parecestes quando mozos, agora nesta idade seu segundo en declarar seus versos ser quisestes.

59 Los CL Psalmos de David (Frankfurt 1626) fol. [7r].

${ }^{60}$ Los CL Psalmos de David (Frankfurt 1626) fol. [7v]. 


\section{Soneto del autor [David Abenatar Melo] al Dios Bendito ${ }^{61}$}

1] ¡Gracias te doy, oh Rey, justo y divino!, firmeza y salvación en mi esperanza, en quien de siempre tuve confianza para llegar al fin deste camino.

2] Conozco que del tal he sido indino, mas tu mano piadosa no se cansa, ¡dichoso aquél que a conocerte alcanza que en ti se apura más que el oro fino!

3] De tu David por tu merced me hiciste que en rudo estilo sus psalmos cantase y palabras que en su boca pusiste.

4] Ahora resta que adelante pase, que pues grandeza tal me concediste, sepa el mundo, Señor, que de Ti nace.

12. Del autor [David Abenatar Melo] al Dios Bendito; [Romance] 62

1] Rey, que a humildes levantas y a polvo abajas soberbios, que das ciencia a los rudos y a los sabios estropiezos, todo con recta justicia que en ti no reina cohecho, que das premio justo al justo y al malo, como él, el premio.

5] Conozco, Señor, de ti y alcanza mi entendimiento que buscas quién no te busca y esto en mí claro lo veo. Conozco también de mí ser de rudeza un portento, aunque en provocarte a sanha no hubo otro más despierto. Tú me viniste a buscar, que yo de ti andaba huyendo,

10] conociendo te debía deuda que pagar no puedo. Muchas veces me llamaste con regalos halaguenhos, y otras con sacarme sangre del alma que ahora siento. Todo porque no seguí lo que mis padres me dieron, que fue la perpetua herencia que va a tu conocimiento.

15] Desvergoncé contra ti veces que no tienen cuento, y Tú de allá me mirabas con paciencia a ver si vuelvo. No tan sólo a ti volví, antes fue mi pensamiento de ensanharte e irritarte con palabra, obra y deseo. Viendo Tú me dé por día, por ti me acudiste luego,

${ }^{61}$ Los CL Psalmos de David (Frankfurt 1626) fol. [268].

${ }^{62}$ Los CL Psalmos de David (Frankfurt 1626) fols. [2r-v]. 
20] y en la Santa Inquisición en homenaje me has puesto. Conocíme, conocíte, y rasgué ante ti mi pecho, n'él viste a mi corazón lleno de arrepentimiento. De allí, Señor, te lhamé, con ojos del alma abiertos, que entonces conocí el alma, que pensé todo era cuerpo.

25] A ojos de mis enemigos y a pesar de todos ellos suelto y libre me sacaste aunque tan malo y protervo. Hecho pedazos salí, no para lo que merezco, porque mis aborrecientes me dieron duros tormentos. Apenas fui conocido de flaco, débil y viejo,

30] ni yo ahora me conozco cuando me miro a un espejo. $\mathrm{Y}$ aún no parando aquí tu merced en mi provecho me trajiste por tu nombre a tomar tu firmamento. Bien pensé me perdonabas hasta allí pecados viejos, y creo bien perdonarás si no los hiciera nuevos.

35] Cuales ellos son, Tú sabes, que los viste y yo los confieso, y otorgo ante ti mis culpas como delincuente reo. Sólo un hijo que tenía después de traerlo al puerto de tu firmamento sacro me lo llevaste a tu cielo. Vilo, quejéme, afligíme con dura ansia y desconsuelo, 40] no osando de levantar los tristes ojos a verlo. Por justo te confesé y por gusto te confieso de más piedad que justicia, atributo, tajo y fuero. Quedé tan desconsolado como viste y en tanto estrecho que si no me das la mano a que más te ofenda temo.

45] Púseme a meldar tu ley, aunque della poco entiendo; mande la continuación, Señor, me hago un deseo: y fue que ver ladinar aquellos divinos versos que tu David te cantaba de mil profecías llenos. Avergonzado también de ver que hay entre tu pueblo

50] para meldar vanidades tan raros entendimientos con tu celo, mas sin ciencia, por darles vergüenza a ellos. Tomé en la mano la pluma mojada en mis descontentos, hice este pobre rascunho en este lienzo pequenho, encolado con mis males que son de color de negro,

55] do los pintores famosos pintan los altos conceptos que pide sujeto tal con el pincel de su ingenio. Mucho me debe David, que siendo yo el más pequenho de tu companha la santa quiera imitarlo en su vuelo. Sirva este pequenho don que ante ti, Señor, presento,

60] en descuento de mis culpas cuantas he contra ti hecho. Que a so l'ombra de tus alas seré seguro y cubierto de toda lengua mordaz que en ella salvarme espero. 
Y pues me quitaste hijos de mi mispaghá ${ }^{63}$ herederos, sírvase tu magestad me sea esto en lugar dellos,

65] hasta que a dármelos vuelvas en aquel dichoso tiempo que a Job tu santo los dobles como a lo demás le has hecho. Este envía en nuestros días, sea por tu merecimiento, y por tu nombre, Adonay, no aguardes, Señor, al nuestro.

13. David Abenatar Melo; [Romance] ${ }^{64}$

1] Con todo mi corazón de día y noche clamo, respóndeme, observaré, Adonay, tus fueros sacros. Apretado, aflicto y triste te llamé para ser salvo y guardar tus testamentos y obedecer tus mandatos.

5] Madrugo por la mañana llamarte como te llamo, que a tu palabra esperé de ella mi refugio y amparo. A las alboradas de ella mis ojos anticiparon para hablar en tus dichos que de alma y corazón amo. Cual tu merced mi voz oye, como tu juicio claro

10] me averigua, ¡oh, Adonay!, mira que en ti es confiado. Los persiguientes maldad, Señor, a mí se llegaron llenos de mal pensamiento con que a tu Ley olvidaron; mas no pudieron conmigo, que cercano a mí te hallaron $\mathrm{y}$ todos tus mandamientos de verdad me sustentaron.

15] Con esto vine a entender, viendo tus raros milagros, que tus testamentos justos para siempre fueron dados.

14. Del Señor Eliachim Castiel In honorem \& gloriam Abrahami Nuñes Bernal qui In Hispania Diem Clausit pro lege Dei exustus quia pius Ipsi obtulit; Epigramma ${ }^{65}$

Quid mentita replet codices celeberrima Phoenix Vitam tune jactans, cum moribunda foco?

Nunc sileant Fabulae dum sunt miracula Nunes, Aeui o Portentum, Martyriique Decus!

5] Quaeso cur tenebras Quaerat per tela, per ignes? Cur instar vitae appetat ille necem?

Diligit ille: mori spernit Qui Verus amator, Si non arsisset, Viveret ille minus ${ }^{6}$.

${ }^{63}$ Hebrew משפח 'family'.

${ }^{64}$ Sylva de diferentes discursos ... fol. $85 \mathrm{v}$. This romance is designated by the transliteration coph, corresponding to the Heb. $\supset$.

${ }^{65}$ Elogios ... Abraham Nüñez Bernal (Amsterdam 1664 or 1665) p. [15].

${ }_{66}$ 'By Sr. Eliachim Castiel, in honor and for the glory of Abraham Nuñes Bernal, who in Spain closed the day [= died], [and] for the Law of God surrendered [his life], burnt [at the stake] because he piously offered himself 
15. Del Señor Joseph Francês de Hamburgo; Soneto ${ }^{67}$

1] Dispuesta al sacrificio la materia en la fragua del ara escandalosa, en cada acción un alma valerosa y un firme corazón en cada arteria.

2] Fija en tu voluntad constante y seria del padre Abraham la marca religiosa, llevan al cielo tu porción gloriosa, dejan al suelo tu mortal miseria.

3] Contra el tirano sin doblarte el ruego de la familia que viviendo amparas un ojo arrancas por dejarle ciego.

4] Ardiente amor, santa amistad declaras, pues cuando para Dios trasciende el fuego para tus hijos se quedó en las aras.

16. Del Señor Joseph Francês de Hamburgo, Epitafio al Jaxam Ishac Jesurum; [Décima] ${ }^{68}$
Aquí de un varão ciente se resolvou o corpo em terra, que desta mundana guerra fêz a humildade valente; da Lei santa ao fogo ardente tanto a matéria apurou que espíritu só ficou, e para subir ligeiro a su centro verdadeiro o pesado aquí ficou.

17. Del Señor Joseph Francês de Hamburgo; [Soneto] ${ }^{69}$

1] Aquel reflejo o rayo cristalino del sol, que os ilumina soberano,

to God. Epigrams.- With what famous lies does the Phoenix fill books, / you presumptuously praising life when lies will perish in the fire? / Now let the stories be silent as long as Nuñes' miracles exist [= are remembered]. / Oh portent (extravagant tale) of the age, glory of the martyr! / Why, I ask, does he seek the shades through weapons and fire? / Why should the image of life seize at death? / This one prizes it; the true lover cultivates death / understanding that had he not burned, he would be living less'.

${ }^{67}$ Elogios ... Abraham Nânez Bernal (Amsterdam 1664 or 1665) p. [17]

${ }^{68}$ D. L. de BARRIos, Relación de los poetas. Refer to no. 36, supra.

${ }^{69}$ In KAYSERLING 1859 pp. 313-314. 
con que en la noche del galut tirano a luz de liberal abrís camino;

2] aquí, como en retrato peregrino, doctas le imprimen vuestra pluma y mano, mostrando fácil el remedio humano en cognocencia del Temor Divino.

3] Éste en que el mismo amor campea tanto en años mozo, en ciencias dilatado, gloria os hace a Israel y al mundo espanto.

4] Rico de vuestro ingenio este tratado, como de erario del lenguaje santo, si era sin precio más será preciado.

18. Del Señor Joseph Francês de Hamburgo, Elogio apologético al Haham David Cohen de Lara; [Octava] ${ }^{70}$
Amante el alto del más bajo mundo por su unión y su vínculo camina $y$ en dulce liga de un amor profundo de la paz simboliza la doctrina; el ente incomprehensible y sin segundo entre los hombres a habitar se inclina, siendo de su grandeza único erario un templo, un sacerdocio, un sanctuario.

19. Versos que fêz meu Señor pai [Ishak de Matatías Aboab] a minha Señora mai índose para Hamburgo a buscar a minha tia Rivca Justa, e era casado de poucos anos; [Décimas] 71

1] Cuando de ti me partí tus ojos negros y hermosos vide triste y llorosos y a llorar me persuadí; pero logo que entendí que en ausencia voluntaria no que temer suerte avara y de prendas rodeada te deixaba consolada, partir no fue acción contraria.

2] Mas después considerando

${ }^{70}$ In KAYSERLING 1859 pp. 313-314.

71 АвОАВ 1683 fol. 29r, London MS.; fol. 28r, Brussels MS. 
la causa de tus enojos, vierten lágrimas mis ojos cuanto me voy alejando; van amor representando tus finezas, tu beldad, y la mucha libertad que fue no desierto amores con que ausente tus calores fuese el amor mitigando.

3] Pues si de prenda choras de nuestro amor fuertes lazos, te deixaba tres en brazos perfetos, vistosos, raros, que mucho te consolaras viendo que ausente de ti también lo estaba de mí: «tata», «nen», Señora, «pecho», que por cada cual los pecha [sic] su amor me olvide de ti.

4] A verte espero volver y decir cuánto es de estima la música de una prima si es prima como mi Ester; entre tanto es menester, pues con los pimpollos tiernos que son lazos sempiternos de nuestro amor te dejé, gozar en ellos mi fe mientras no es posible vernos.

Finis laus Deo

20. Rehuel Jessurun; [Romance] ${ }^{72}$

1] Para que em voz sonora cantara seus louvores ser rouxinol quisera dêstes sagrados montes. Quisera ser mais libre e de les não tão longe, mais ausente e cativo canto alegre não sofre.

5] Com todo, em quanto as sombras desta pesada noite poem trégoa a meus receos e engano a meus temores,

72 Dialogo dos montes (Amsterdam 1624) fol. [24v, Act 1]: «Os músicos». 
razão será que cessem meus olhos de ser fontes, póndoos nos cumes altos donde meu bem se esconde. Pois nas penas e glórias meus companheiros fostes

10] e a vós sou comparado no ser firme e imóvel. Lembremos bems passados, presentes disfavores, porque esperansas firmes nossos males consolem. Se a vós desconheserdes, disculpai, pátrios montes, quem por tão largos anos os estrangeiros sofren.

15] Pode o legeiro tempo mudar formas e vozes, porém vossas lembranças nunca tirar mais pode.

\section{Rehuel Jessurun; [Romance] ${ }^{73}$}

1] Presente em Sion vejo de meus progenitores a prova da fé pura que ainda imitamos hoje, se faltão sacrifícios, que meus êrros perdoem, promesas imfaliveis nosso temor socorrem. Té ver o alegre dia em que meus salvadores desde teus cumes altos minha verdade mostrem.

\section{Rehuel Jessurun; [Romance] ${ }^{74}$}

1] Se em Sinay ponho os olhos, a voz se gela e o bronze de meu coração duro em mil partes se rompe. Se vós admira o verme, meo mal não vos assombre, que poden meus delitos mudar glórias majores.

5] Mais não que haja mudança em quem já mais a ouve, nem que o concerto eterno que en vós se deu, se troque.

\section{Rehuel Jessurun; [Romance] ${ }^{75}$}

1] E vós, depositário do sumo Sacerdote, que desprezando a vida deteve tantas mortes; Vós, que em seu trance ouvistes meus lamentos entonces por meu mal renovados com causas não menores.

5] Que muito que este fogo se dilate e prolongue!, Té que das cinzas frias qual fénix me renove.

73 Diâlogo dos montes fol. [32r, Act 1]: «Os músicos».

74 Diâlogo dos montes fol. [35r, Act 1]: «Os músicos».

${ }^{75}$ Diâlogo dos montes fol. [38v, Act 1]: «Os músicos». 
24. Rehuel Jessurun; [Romance] ${ }^{76}$

1] O vós, túmulo santo, fiel erário a onde a incomprehensívelmente seu fiel servo incobre! Nas profundas cavernas de vosso peito soem os amorosos ecos destas lembranças doces.

5] Até que das entranhas em vez de ervas e flores a alegre madre terra vivientes corpos brote.

25. Rehuel Jessurun; [Romance] ${ }^{77}$

1] Se de Guerizim vejo a alevantada fronte na presente baixesa meu ánimo se encolhe. Lembrando glórias tantas, bendições e favores, que hoje o contrário vejo por delitos enormes.

5] Até que passe a ira que o sol que se me esconde destas secas raízes fértis plantas renove.

26. Rehuel Jessurun; [Romance] ${ }^{78}$

1] E vós, monte felice, ara sagrada a onde sacrificou meu zêlo a superstição torpe. Ser Adonay, Deus, firme, gritando em altas vozes, sou por largo espácio pelos vezinhos montes.

5] Se há hoje quem discrepe cedo espero que torne, quem corações divisos fassa brandos e acordes.

27. Rehuel Jessurun; [Romance] ${ }^{79}$

1] Vós, monte das olivas, que em meu delúvio forte me dais indícios claros de cessarem rigores; Quando o tribunal santo verei que o mundo otorgue a sentença do pleito que ainda trazemos hoje?

5] Mostre, o Senhor, seu braço, véjase sobre os montes, quem de seu reino eterno novas glórias pregõe.

28. «De un señor de Hamburgho»; [Décimas] ${ }^{80}$

1] Nace el hombre, y de la cuna buscando el túmulo incierto, dudoso entre vivo y muerto,

\footnotetext{
76 Diâlogo dos montes fol. [41r, Act 1]: «Os músicos».

77 Diâlogo dos montes fol. [43v, Act 1]: «Os músicos».

78 Diâlogo dos montes fol. [46r, Act 1]: «Os músicos».

79 Diâlogo dos montes fol. [49r, Act 1]: «Os músicos».

80 Elogios ... Ishak de Castro Tartás 1648? ff. [98r-99r].
} 
vaga sin quietud alguna

en un cuerpo, en alma una; liga de paz transitoria, moviendo guerra notoria que o le salva o le condena, glorias le destinan penas, penas le destinan glorias.

2] Si abraza del apetito sin luz real lo aparente, solicita infelizmente pena para su delito; mas si inculpable o contrito al freno de la razón sujeta su inclinación no aparente, antes real, rayo de luz inmortal glorifica su elección.

3] Sale a luz en noche obscura Ishack en región extraña, donde la malicia baña su inocencia en agua impura; mas tanto que ve segura la elección que al alma importa, el pacto de Abraham le exhorta al sacrificio que paga, ... [verse missing] su cuchillo sí que corta.

4] Si el predestinado viene (dicen) para salvación, y el precito es opinión que sabido el daño tiene, d'este el hábito previene tanto temor al pecado $y$ resiste tan osado las fuerzas de su apetito que si naciera precito se hiciera predestinado.

5] Sigue el precepto divino como del alma alimento, mas de la vida el sustento le fuerza a andar peregrino; saltéale en el camino 
el lobo, ladrón feroz, sordo a tanto llanto y voz, vara que inquiere el registro del alma, y de Dios ministro usurpa el oficio a Dios.

6] En su prisión, sepultura de vivientes, le acaricia falsa piedad y justicia, crisol que inmundando apura; mas el que sólo un Dios jura de sacrificar su vida, ganada cuando perdida por la soberana causa, que usa de piedad sin pausa de justicia con medida.

7] Dícenle que al mar incierto del mundo nadando entró, que el agua en que naufragó puede reducirle al puerto, que es sello y hábito cierto que al alma señala y viste, que si en ser muralla insiste al fuego hallará trabuco; responde, cual a Nabuco: «sabia juventud resiste».

8] Si en agua no hay firme letra, la vuestra imprimir es yerro; mi marca abierta con hierro hasta lo inmortal penetra, como cuesta sangre impetra blasón firme y verdadero, sin mudarse más espero vencer mi adversario atroz, que el buen soldado de Dios no sabe ser bandolero.

9] La mancha que en mí confieso limpie la llama en su fragua, borre el carácter del agua que decís que tengo impreso; ya será de culpa exceso, 
que con este aviso peque $\sin$ que tal vestido trueque $y$ en reliquias de naufragio el fuego sí que es sufragio para que el agua se seque.

10] Uno solamente es Dios, y por su glorioso nombre no hay tormento que me asombre ni muerte que juzgue atroz; a su tribunal mi voz clama de vuestra violencia, no importa que mi inocencia culpéis, si con Dios la abono que Éste sólo ocupa el trono de integridad y clemencia.

11] Movidos de la eficacia de estabilidad tan fuerte, con la más tirana muerte mandan reprimir su audacia; condenan por pertinacia condenar a un Dios criador; quieren que vivo el rigor del fuego sufra, joh dilirio!, que le apliquen por martirio y a su lisonja mayor.

12] Sales al mortal suplicio, nuevo Ishack, que al santo i[mitas] en fe, aunque solicitas notorio tu sacrificio; contra el sofístico vicio la verdad que te celebra allí sin mella ni quiebra mantiene en pública plaza que aunque dicen que adelgaza, ni adelgaza ni se quiebra.

13] La pira erigida en alto, formidable a quien la m[ira] a tus ojos no fue pira de error ni de sobr[esalto]; firme en ella a todo asa[lto] 


$$
\begin{aligned}
& \text { muestras al contrario ... } \\
& \text { que con tu Dios va ... } \\
& \text { de entrar su divin[idad] } \\
& \text { y haciendo la hoguera ... } \\
& \ldots \text { [verse missing] }
\end{aligned}
$$

\section{FIRST-VERSE INDEX}

Amante el alto del más bajo mundo (18), Joseph Francês Aquel reflejo o rayo cristalino (17), Joseph Francês. Aquí de um varão ciente (16), Joseph Francês. As virtudes e ciência que mostrares (8), Anon. Con todo mi corazón (13), David Abenatar Melo Cuando de ti me partí (19), Ishak de Matatías Aboab Davão do nome as obras bom indício (10), Anon. Dispuesta al sacrificio la materia (15), Joseph Francês E vós, depositário (23), Rehuel Jessurun E vós, monte felice (26), Rehuel Jessurun Entre as chamas corroscantes (4), Joseph Francês ¡Gracias te doy, oh Rey, justo y divino! (11), David Abenatar Melo Hic docet in Lingua proprioque idiomate Moses (2), Jacob Rosales Ito per docti meditantis ora (1), Jacob Rosales Mucho alienta al cansado su reposo (7), Anon. Na lusitana língoa, que a memória (5), Ishak Abás Nace el hombre, y de la cuna (28), Anon. ¡O músico real na hebrea lira! (6), Anon. ¡O vós, túmulo santo! (24), Rehuel Jessurun Para que em voz sonora (20), Rehuel Jessurun Penetrar os sofísticos enganos (3), Daniel Abudiente Presente em Sion vejo (21), Rehuel Jessurun Quem viu em verso heróico tal conceito (9), Ishak de Herrera Quid mentita replet codices celeberrima Phoenix (14), Eliachim Castiel Rey, que a humildes levantas (12), David Abenatar Melo Se de Guerizim vejo (25), Rehuel Jessurun Se em Sinay ponho os olhos (22), Rehuel Jessurun Vós, monte das olivas (27), Rehuel Jessurun

81 The manuscript text is incomplete. In 1725, the Philadelphia bibliophile James Logan purchased it from Isaac Miranda. Logan informs us in a note attached to the text that Miranda «tore out the first pages or the first twelve leaves of it». 


\section{RESUMEN}

El presente artículo es la primera entrega de un trabajo, cuya segunda parte aparecerá también en Sefarad. Incluye una introducción histórica y evaluativa, y textos de poemas en español, portugués y neolatín escritos en los siglos XVII y XVIII por sefardíes de Hamburgo. Examinados aisladamente, los poemas que componen este poemario muestran poca creatividad; pero si se consideran como la aportación de los sefardíes diaspóricos a un fenómeno pan-europeo, se observa que nos encontramos ante un intento de recrear y desde luego crear un nuevo discurso literario.

\section{SUMMARY}

This is the first of a two-part study the intention of which is to reproduce and evaluate Spanish, Portuguese, and Neo-Latin poetry written by 17 th and 18th- century Hamburg-based Sephardim. The general conclusion is that considered in isolation these poems are, at best, circumstancial and of limited creative significance, but when considered as part of a pan-European literary phenomenon they represent an attempt to create a new literary discourse. 